\title{
An Examination of the Effect of Employee Involvement on Teamwork Effectiveness: An Empirical Study
}

\author{
Mahfuz Judeh \\ Associate Professor, Department of Business Administration, Applied Science University \\ P. O. Box 166, Amman 11931, Jordan \\ Tel: 962-796-658-877 E-mail: maj4040@hotmail.com
}

Received: March 18, 2011 Accepted: April 7, 2011 doi:10.5539/ijbm.v6n9p202

\begin{abstract}
The aim of this study was to determine the level of employee involvement and extent of teamwork effectiveness among employees working in the Jordanian glass and ceramic industries listed in Amman Stock Exchange in Jordan. The study aimed also at examining the significant effect of employee empowerment on teamwork effectiveness. Furthermore, the study investigated the significant differences that may exist in employee involvement due to differences in age, marital status, and educational level.

Data were collected from 176 participants and then analyzed using descriptive statistics, one sample t-test and independent sample t-test, linear regression, and ANOVA. Findings indicated that both employee involvement and teamwork effectiveness were at a high to moderately high level score. Furthermore, the findings of the study revealed a significant effect of employee involvement on teamwork effectiveness. At the same time results indicated that there were no significant differences towards employee involvement due to gender or marital status, while participants significantly differed in terms of educational level.

The results of this study had many implications for human resources and other practitioners and managers who must enhance the teamwork atmosphere in their organizations. As for the originality/value, employee involvement and teamwork effectiveness had previously lacked attention, especially in the Middle East countries, and this paper contributed to the body of knowledge by empirically studying the correlation between employee involvement and teamwork effectiveness.
\end{abstract}

Keywords: Employee involvement, Teamwork effectiveness, Glass and ceramic industries, Human resource management, Jordan

\section{Introduction}

In efforts to increase organizational effectiveness, employee involvement has been an area of recent interest and academic concern. Employee involvement has been linked to many different management concepts and behaviors, such as, management styles, total quality management, employee empowerment, job satisfaction, and job performance.

Cohen's (1999) research argued employee involvement as an antecedent to organizational commitment. It goes without saying that employees with high level of involvement are expected to work harder than those with low level of involvement. Employee with high level of involvement could be described as one whose job is the center of his/her life. As such, many theorists have hypothesized that employee with high level of involvement will put forth substantial effort towards the achievement of organizational objectives and be less likely to turnover (e.g. Kahn, 1990; Lawler, 1986).

Indeed, employees with high level of involvement seem to be satisfied with their jobs, to have positive moods at work, and to be highly committed to their employers, and their careers (Carson et al., 1995; Cohen, 1995).

Many studies showed that the understanding of the importance of employee involvement by employer is essential to managers because this is a significant predictor of work behavior among employees (e.g. Manojlovich, Laschinger, \& Heather, 2002). Other studies emphasized job involvement, organizational identification, and organizational commitment as important positive work attitudes (e.g. Lee 1971, Kanungo 1982, Blau 1985). The results of Blau's (1986) study indicated that interactions between employee involvement and organizational commitment were significant predictors for unjustified lateness and absence.

Organizations often rely on teamwork for continuous improvement of their products and services, and also of all other organizational functions. For example, some estimates claim $80 \%$ of companies with 100 or more employees rely on teams and groups for their everyday work (Cohen \& Bailey, 1997). 
Team effectiveness is important because it is one of the most important determinants of the companies' success. Drucker (1974, p. 561) defines effectiveness as "the extent to which the desired result is realized". Effective teams are teams who can achieve high standards of task performance, and reach high levels of satisfaction for their members.

Previous studies found that positive work group experiences and effectiveness can enhance employees' satisfaction and minimize turnover intentions (Cohen and Bailey, 1997; Hom et al., 1984).

Schermerhorn $(2008$, p. 397) stated that the main teamwork pros are the synergy, which means the creation of a whole that is greater than the sum of its parts, because synergy pools individual talents and efforts to create extraordinary results. While at the same time, teamwork has its advantages, such as social loafing. Social loafing refers to the tendency for individuals to exert less effort when working with the team than when working individually (Comer, 1995). Despite the fact that teams are usually expected to improve organizational effectiveness, several challenges exist to teamwork (Passos and Caetano, 2005). Other problems which are visible more to personal experience than in text, such as cultural barriers and communication problems can deter group cohesion (Conti and Kleiner, 1997). Another problem teams experience is lack of visible support and commitment from top management (Harrington, p. 21).

Although having the right inputs available to a team is important, it is not a guarantee of effectiveness, since group process counts too (Schermerhorn $(2008,405)$. Moreover, clearly defined goals should be specific in such a way that leads the actions to be taken by the team. Andia (1998) stated that values, vision, and mission provide direction for team members to identify with a common goal and understand what motivates their performance as a team.

Furthermore, team leader should guide team members to direct their efforts and focus their commitment towards the goals of the team. Team members should be committed to the specified goal of their team and should participate in its development (Simon, 2001). Commitment within the team members to the overall goals of the team is a crucial factor for the team success. The team leader is directly responsible for inspiring this commitment from team members so as to enhance the team efforts in achieving the common goals.

\section{Literature Review}

\subsection{Job Involvement}

Job involvement refers to the extent to which an individual's psychological identification to his / her job (Kanungo, 1982). It is the degree to which an employee is cognitively preoccupied with, engaged in, and concerned with his/her job (Paullay et al., 1994). Job involvement involves how an employee has a sense of controlling his work, receiving information about performance, and being rewarded for the results of the organization (Lawler et al, 1992, p. 2). Rabinowitz and Hall (1977) defined job involvement as the result of interactions between the personal traits and the personal response to the influence from an organization or situation.

Lawler studies demonstrated the benefits that could be derived from carefully planned and implemented employee involvement programs. To be effective, employee involvement initiatives need to be tied to other human resources activities such as compensation systems and performance appraisals (Lawler, 1971; Mohrman et al., 1989).

Having received benefits from the organization, employee has to repay them as a matter of reciprocity. So, it may be expected that the more an organization is fair and generous to the employee whose job is the major satisfaction in his/her life, the greater an employee's job involvement will be. Thus, employee involvement can be conceptualized the importance of work which stay in the individual's total self-image" (Lodahl \& Kejner, 1965; p. 24).

In general, the degree of involvement varies from task, section, and department to corporate level. At the same time, the range of subject matters dealt with varies from strategic, operational to task-related decisions (Wimalasiri and Kouzmin, 2000).

Employee involvement influences many important work outcomes, such as absenteeism, turnover, performance and job satisfaction (Brown 1996). Many theorists have hypothesized that highly job-involved employees will exert substantial effort towards achieving organizational objectives and are less likely to turnover (e.g. Kahn, 1990; Kanungo, 1979). Chu et al. (2005), Hoffi-Hofstetter and Mannheim (1999), and Chughtai (2008) uncovered a significant relationship between employee involvement and organizational citizenship behaviors. Rotenberry and Moberg (2007), citing Munene (1995), found a substantial, positive relationship between employee involvement and the conscientiousness component of supervisor-rated citizenship behavior. Bandura (1977) argued that there is a strong correlation between employees' self-efficacy and employee involvement. A relationship between employee involvement and job satisfaction was identified in Soong's (2000) study. In general, many researchers consider employee involvement to be a primary determinant of organizational effectiveness (Pfeffer, 1994).

As for dimensions of employee involvement, the "Job Involvement Inventory" developed by Kanungo (1982) could be classified into three categories, consisting of "work concentration", "work evaluation" and "work identification". Cai (2001) divided employee involvement into the five dimensions: "work concentration", "work evaluation", "work identification", "work participation" and "fun from work". Alternatively, Yang et al (2006) divided employee involvement \into four dimensions, consisting of "fun in work", "work evaluation", "work 
identification", and "work concentration".

Fostering employee involvement is an important organizational objective because it is expected in this study that employee involvement will be a primary determinant of teamwork performance.

On the basis of the above discussion, the following hypothesis was tested.

H1a: There is a significant level of employee involvement among employees working with the Jordanian Glass and Ceramic industries listed in Amman Stock Exchange in Jordan.

\subsection{Teamwork}

Teams and teamwork have received considerable attention from social and organizational psychologists over the last decades (Guzzo and Shea, 1992). Successful team leaders who are able to promote care and trust values find themselves with high standards of teamwork effectiveness which would affect their organization's competitiveness (Cohen and Bailey, 1997).

There are many types of teams in organizations, each created to accomplish a specific goal. Bateman and Snell (2007, p. 462), for example, mentions work teams, project and development teams, parallel teams, management teams, transnational teams, and virtual teams. Huszczo (1990), for example, mentions committees, task forces, quality circles, employee participation groups, joint union-management teams, action committees, project teams, supervisory councils and autonomous or self-directed work teams.

Virtual teams exist where the locations of team members prevent them to meet face-to-face. Geister, Hertel and Konradt (2002) argued that virtual teams offer several strategic advantages for organizations and employees, for example, connecting competent employees for a project regardless of their location, providing greater flexibility to individuals, and saving expenses for traveling and office equipment.

In comparison to traditional face-to-face teams, virtual teams often show lower performance levels in terms of group effectiveness and the time needed to reach decisions (Baltes, Dickson, Sherman, Bauer, \& LaGanke, 2002; Hollingshead \& McGrath, 1995). Virtual teams also show lower levels of other outcome variables, such as group cohesion and work satisfaction (Baltes et al., 2002; Warkentin, Sayeed, \& Hightower, 1997).

Roles of teams are very crucial. According to Belbin (1981), the most successful teams have a distribution of the eight specific team roles: co-coordinator or chairman; shaper; plant; monitor-evaluator; implementer or company worker; resource investigator; team worker; finisher.

Bateman, Wilson and Bingham (2002) developed a team effective questionnaire which was clustered around six core themes: shared team synergy, clear performance objectives, team members skills, effective use of resources, innovation, and quality. Bateman and Snell (2007, p. 467), citing Nadler et al (1979) stated that team effectiveness is defined by three criteria: First, the productive output of the team meets or exceeds the standards of quantity and quality; the team's output is acceptable to those customers, inside or outside the organization, who receive the team's products or services.

Second, team members realize satisfaction of their personal needs, and third, team members remain committed to working together again; that is, the group doesn't burnout after a grueling project. Adams et al. (2002) identified seven characteristics as the main elements for effective teams: productive conflict resolution, mature communication, role clarity, accountable interdependence, goal clarification, common purpose and psychological safety. Hackman (1990) defines team effectiveness as the degree to which a team's output meets requirements in terms of quantity, quality, and timeliness (performance); the team experience improves its members' ability to work as a team in the future (behavior), and the team experience contributes to individual satisfaction (attitude).

Bateman and Snell (2007) citing Tuckman (1965) stated that for teams to be developed successfully, they should engage in various activities, including:

- Forming: group members attempt to lay the ground rules for what type of behavior are acceptable.

- Storming: hostilities and conflict arise, and people start seeking for power.

- Norming: group members agree on their shared goals and norms.

- Performing: the group channels its energies into performing its tasks.

Bateman and Snell (2007) added that groups who deteriorate move to a declining stage, and temporary groups add an adjourning or terminating stage.

Often work teams are allowed to self-manage their team processes, that is, the team has the authority and responsibility to manage how their team functions (Solansky, 2008).

Nevertheless, the selection process should concentrate on selecting the candidates who have the teamwork spirit and expected to be good team members, and at the same time, management should develop and foster an appropriate teamwork culture.

Based on the above discussion of literature, the following hypotheses are tested:

H2a: The work teams in the Jordanian Glass and Ceramic industries Listed in Amman Stock Exchange in Jordan are significantly effective. 
H3a: There is a statistically significant positive effect of employee involvement on work teams effectiveness.

\section{Methodology}

\subsection{Research design}

This study investigates the effect of employee involvement on teamwork effectiveness through a descriptive and analytical methodology. The current study depends on a field, nonexperimental design, for testing the hypotheses. The major weakness of a nonexperimental design is the lack of control over independent variables and the specific identification of causality; however, it provides the opportunity for a noninvasive examination of the variables of interest over a wider range of organizations (Emery and Barker, 2007). The survey instrument adopted for this study was a questionnaire. Questionnaire is the most appropriate instrument to be used in the literature of employee involvement.

The first two hypotheses (H1a and H2a) are examined through utilizing a one sample t-test, and (H3a) is addressed with a regression analysis. The Statistical Package for Social Science (SPSS) version 16.0 was used to analyze the data.

\subsection{Sample and Data Collection}

Population constitutes supervisors and employees working in the Jordanian glass and ceramic industries listed in Amman Stock Exchange in Jordan. A total of 300 questionnaires were distributed accompanied with cover letter assuring confidentiality of data and results. The author when handed over the questionnaires to the participants, he requested them to fill the questionnaires on the spot. Some of the participants preferred to fill the questionnaire on the spot while others were given one week to fill the relevant questionnaires.

Out of the whole distributed questionnaires, 182 were returned. The author discarded 6 questionnaires because they were filled with excessive missing data. After the deletion of the invalid responses, the author obtained 176 valid questionnaires, yielding a response rate of $58.7 \%$.

\subsection{Measures}

\subsubsection{Employee Involvement}

Employee involvement questionnaire was adopted from the study of Lodahl and Kejner (1965) and partially adjusted through selecting ten relevant items from their questionnaire along with developing four additional items. An example is "The major satisfaction in my life comes from my job". This measure scaled in a five-point Likert scale ranging from 1 (completely disagree) to 5 (completely agree). The scores obtained on each of the 14 items were averaged to produce a single score for employee involvement. The higher the score, the higher job involvement perceived by the sample is. Cronbach`s alpha for this scale as shown on Table (1) was 0.879 , therefore meeting the criterion of 0.70 proposed by Nunnaly \& Bernstein (1994).

\subsubsection{Teamwork Effectiveness}

As for teamwork effectiveness, it was measured using an 8-item scale developed by the author based on the study literature. This measure was built on a five-point Likert scale $(1=$ completely disagree to $5=$ completely agree $)$. The scores obtained on each of the 8 items were averaged to produce a single score for teamwork effectiveness. A higher score indicated that the participant perceived a greater degree of team effectiveness in the workplace. The value of coefficient alpha for this sample as shown on Table (1) was 0.854 , therefore indicating good reliability.

\subsubsection{Control Variables}

Three control variables included in this study were: gender, marital status, and education level. Respondents were also asked to report their gender and marital status, which were coded (male $=1$ and female $=2$ ) for gender, and ( single $=1$ and married $=2)$ for marital status. Regarding education level, In the data compilation, responses to were based on a four-point Likert format ranged from 1= elementary school to $4=$ bachelor's agree.

\section{Results}

Demographic characteristics of the sample were analyzed. Majority of the sample (76.7\%; 135 persons) were male. Most of the sample (54.0\%; 95 persons) were married. Among the 176 participants (35.8\%; 63 persons) had high school level of education, followed by community college certificate holders ( $29.0 \%$; 51 persons). Around 43 of participants $(24.4 \%)$ were a Bachelor's degree holders, while a small percentage of participants $(10.8 \% ; 19$ persons) had elementary school level of education.

An independent samples t-test was computed in order to investigate whether female participants differ significantly on employee involvement from their male counterparts. Results in Table (1) indicated that there were no significant differences in employee involvement based on gender $(t=1.006 ; p>.05)$. Furthermore, results indicated that there were no significant differences in employee involvement based on marital status $(\mathrm{t}=$ $1.168 ; \mathrm{p}>.05)$.

ANOVA was used to investigate the differences in employee involvement score due to educational level. Results in Table (1) showed that there were significant differences in employee involvement due to level of education $(\mathrm{F}=$ $4.631 ; \mathrm{p}<.01)$. 
The descriptive statistics were used to describe the correlation between study variables.

Table (2) shows the means, standard deviations, and the reliability of the variables used in this study. The overall mean $($ Mean $=4.254, \mathrm{SD}=0.492)$ for employee involvement was reasonably high. The respondents reported moderately high levels of teamwork effectiveness (Mean $=3.962, \mathrm{SD}=0.706$ ).

One sample t-test was conducted to explore if there was a significant level of employee involvement among employees working with the Jordanian Glass and Ceramic industries listed in Amman Stock Exchange in Jordan. Table (3) showed the results which revealed support for H1a $(\mathrm{t}=33.846, \mathrm{p}<.01)$. Moreover, teamwork effectiveness scores also significantly proved support for $\mathrm{H} 2 \mathrm{a}(\mathrm{t}=18.082, \mathrm{p}<.01)$.

Regarding H3a, regression analysis was applied as a statistical tool to explore the effect of employee involvement on the dependent variable, teamwork effectiveness. Examination of the results shown on Table (4) revealed that employee involvement exhibited a significant effect on teamwork effectiveness $\left(\right.$ Beta $\left.=.795, \mathrm{R}^{2}=.632, \mathrm{p}<.01\right)$. The findings indicated support for $\mathrm{H} 3 \mathrm{a}$.

The current study contributes to the literature by providing empirical evidence that employee involvement positively affects the teamwork performance and effectiveness through, so the management of organization may follow appropriate techniques to encourage employee involvement, which should positively affect the spirits and cohesiveness of work teams.

\section{Discussion and Conclusions}

The present study aimed at exploring the level of employee involvement as well as the effectiveness of work teams among employees working with the Jordanian glass and ceramic industries listed in Amman Stock Exchange in Jordan. Furthermore, the study aimed at examining the effect of employee involvement on work team's effectiveness. The conclusions of this study provide further support for the correlation between employee involvement and teamwork effectiveness.

In Hypothesis 1, it was postulated that there was a statistically significant level of employee involvement among employees working with the Jordanian glass and ceramic industries listed in Amman Stock Exchange in Jordan. Results supported this hypothesis.

In Hypothesis 2, it was assumed that work teams in the Jordanian glass and ceramic industries listed in Amman Stock Exchange in Jordan are significantly effective, and H2a was supported too.

The results established the relationships between employee involvement as antecedent of teamwork effectiveness. This suggests that the greater the employee involvement is, the higher the level of teamwork effectiveness.

As for demographic characteristics, results indicated that there were no significant differences in employee involvement based on gender. Such results are consistent with results of the studies of Burke (2002); and Cortis and Cassar (2005) indicating no gender differences regarding employee involvement of male and female respondents.

Results also indicated that there were no significant differences in employee involvement due to marital status. This result tallies with results of Cortis and Cassar (2005) that no significant difference on employee involvement between married and unmarried were reported. Moreover, results showed that there were significant differences in employee involvement due to level of education. Such result is consistent with Yang et al (2006) indicating no significant difference is observed in the level of education received.

The results of this study have many implications for human resources practitioners and managers who should enhance the teamwork atmosphere in organization. These findings could be extended beyond the research's original purpose in the field of glass and ceramic industry in Jordan.

In order to attain high employee involvement, management should make access to information available for employees and should also encourage them and give them the opportunity to make remarkable contributions.

\section{Limitations and Directions for Future research}

As with any research, there are limitations that should be taken into consideration when planning to carry out the practical application. First, this study was based on information gathered at one point in time. More accurate findings of the study could have been better inducted with a longitudinal approach. Although the sample of the study was statistically valid, the population or the number of companies working in the glass and ceramic industries listed in Amman Stock Exchange was limited, which could, to a certain limit, affect the generalizability.

Another issue related to data gathering process that may limit generalizability of the results was the fact that many supervisors transferred the questionnaires given to them to their assistants or colleagues to fill them out. One of the other limitations of this study was the unbalanced distribution of gender variable in the sample chosen, where $76.7 \%$ of the sample were male. This may cause some bias or distortion and ambiguity in conclusions.

The current study was carried out in the context of a specific sector in Amman Stock Exchange in Jordan.

The author recommended that further investigation should be conducted by other practitioners and researchers. 
Further research may be conducted in other sectors in order to validate the findings of this study. In particular, researchers are encouraged to examine the antecedents of employee involvement variable.

It is proposed that future research can be conducted in a wider range of employees' work-related outcomes such as role stressors, and organizational commitment can be added into a more comprehensive study. Future researchers may extend this study by investigating the mediating variables, such as orientation, training, trust, and organizational citizenship behaviors, linking employee involvement and teamwork effectiveness.

Future research could explore the role of management in encouraging employee involvement and enhancing teamwork performance and effectiveness. The psychological relationship between employee involvement and teamwork effectiveness in large manufacturing context, inside or outside Jordan, could be another direction for further investigation.

\section{References}

Adams, S., Simon, L., and Ruiz, B. (2002). A pilot study of the performance of student teams in engineering education. Proceedings of the American Society for Engineering Education Annual Conference and Exposition, Montreal.

Andia, L.M. (1998). How to train with a partner (and not come to blows). Training \& Development, Vol. 52 No. 5 , pp. 14-15

Baltes, B. B., Dickson, M. W., Sherman, M. P., Bauer, C. C., \& LaGanke, J. S. (2002). Computer-mediated communication and group decision making: A meta-analysis. Organizational Behavior and Human Decision Processes, 87, 156-179. doi:10.1006/obhd.2001.2961, http://dx.doi.org/10.1006/obhd.2001.2961

Bandura, A. (1977). Self-efficacy: toward a unifying theory of behavioral change. Psychological Review, Vol. 84 No. 2, pp. 191-215. doi:10.1037/0033-295X.84.2.191, http://dx.doi.org/10.1037/0033-295X.84.2.191.

Bateman, Billy, Wilson, F. Colin and Bingham, David. (2002). Team effectiveness - development of an audit questionnaire. Journal of Management Development, Vol. 21, No. 3, 215-226. doi:10.1108/02621710210420282, http://dx.doi.org/10.1108/02621710210420282

Bateman,Thomas S., and Snell, Scott A. (2007). Management: Leading \& Collaborating in a Competitive World, 7th Edition. McGraw-Hill Irwin, New York.

Belbin, M. (1981). Management Teams, Why They Succeed or Fail. Butterworth-Heinemann, Stoneham, MA.

Blau G.J. (1985). A multiple study investigation of the dimensionality of job involvement. Journal of Vocational Behavior, 27, 19-36. doi:10.1016/0001-8791(85)90050-8, http://dx.doi.org/10.1016/0001-8791(85)90050-8

Blau, G. J. (1986). Job involvement and organizational commitment as interactive predictors of tardiness and absenteeism. Journal of Management, 12, 577-584. doi:10.1177/014920638601200412, http://dx.doi.org/10.1177/014920638601200412

Brown S.P. (1996). A meta analysis and review of organizational research on job involvement. Psychological Bulletin, 120(2), 235-255. doi:10.1037/0033-2909.120.2.235, http://dx.doi.org/10.1037/0033-2909.120.2.235

Burke, R.J. (2002). Organizational values, job experiences and satisfactions among managerial and professional women and men: advantage men?. Women in Management Review, Vol. 17, No. 5, pp. 228-36. doi:10.1108/09649420210433184, http://dx.doi.org/10.1108/09649420210433184

Cai, L. H. (2001). The relationship between the job involvement and teaching effectiveness for the Elementary school of Taipei County. Unpublished master's thesis.

Carson, K.D., Carson, P.P., and Bedeian, A.G. (1995). Development and construct validation of a career entrenchment measure. Journal of Occupational and Organizational Psychology, Vol. 68, pp. 301-20.

Chu, C., Lee, M., Hsu, H., and Chen, I. (2005). Clarification of the antecedents of hospital nurse organizational citizenship behavior - an example from a Taiwan regional hospital. Journal of Nursing Research, Vol. 13, 313-24. doi:10.1097/01.JNR.0000387554.73328.32, http://dx.doi.org/10.1097/01.JNR.0000387554.73328.32

Chughtai, Aamir Ali. (2008). Impact of Job Involvement on In-Role Job Performance and Organizational Citizenship Behaviour. Institute of Behavioral and Applied Management.

Cohen, A. (1995). An examination of the relationships between work commitment and nonwork domains. Human Relations, $\quad$ Vol. $48, \quad$ pp. 239-63. doi:10.1177/001872679504800302, http://dx.doi.org/10.1177/001872679504800302

Cohen, A. (1999). Relationships among the five forms of commitment: an empirical analysis. Journal of

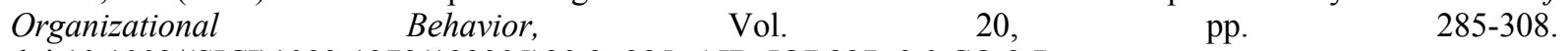
doi:10.1002/(SICI)1099-1379(199905)20:3<285::AID-JOB887>3.0.CO;2-R, http://dx.doi.org/10.1002/(SICI)1099-1379(199905)20:3<285::AID-JOB887>3.0.CO;2-R

Cohen, S. G., and D. E. Bailey. (1997). What Makes Teams Work: Group Effectiveness Research From the Shop Floor to the Executive Suite. Journal of Management, 23, 239-264. doi:10.1177/014920639702300303, http://dx.doi.org/10.1177/014920639702300303 
Comer, D.R. (1995). A model of social-loafing in real work groups. Human Relations, June 1995, 647-667. doi:10.1177/001872679504800603, http://dx.doi.org/10.1177/ 001872679504800603

Conti, Betty and Kleiner, Brian H. (1997). How to increase teamwork in organizations. Training for Quality Volume, 5, 26-29. doi:10.1108/09684879710156496, http://dx.doi.org/10.1108/09684879710156496

Cortis, Rachelle and Cassar, Vincent. (2005). Perceptions of and about women as managers: investigating job involvement, self-esteem and attitudes. Women in Management Review, Vol. 20 No. 3, pp. 149-164. doi:10.1108/09649420510591834, http://dx.doi.org/10.1108/09649420510591834

Drucker, P.F. (1974). Management: Tasks, Responsibilities, Practices. Heinemann, London.

Emery, Charles R., and Baker, Katherine J. (2007). Effect of commitment, job involvement and teams on customer satisfaction and profit. Team Performance Management, Vol. 13, No. 3/4, 90-101. doi:10.1108/13527590710759847, http://dx.doi.org/10.1108/13527590710759847

Geister, Susanne, Hertel, Guido and Konradt, Udo. (2006). Effects of Process Feedback on Motivation, Satisfaction, and Performance in Virtual Teams. Small Group Research, Vol. 37, No. 5. 459-489. doi:10.1177/1046496406292337, http://dx.doi.org/10.1177/1046496406292337

Guzzo, R.A., and Shea, G.P. (1992). "Group performance and intergroup relations in organizations", in Dunnette, M.D. and Hough, L.M. (Eds), Handbook of Industrial and Organizational Psychology, Vol. 3, Consulting Psychology Press, Palo Alto, CA, 269-313.

Hackman, J.R. (1990). Groups that Work (and Those That Don't). Jossey-Bass Publishers, San Francisco, CA.

Harrington, Mackin, D. (1994). The Team Building Tool Kit, American Management Association. New York, NY, 1994.

Hoffi-Hofstetter, H., and Mannheim, B. (1999). Managers' coping resources, perceived organizational patterns, and responses during organizational recovery from decline. Journal of Organizational Behavior, Vol. 20 No. 5, pp. $665-85$. doi:10.1002/(SICI)1099-1379(199909)20:5<665::AID-JOB920>3.0.CO;2-V, http://dx.doi.org/10.1002/(SICI)1099-1379(199909)20:5<665::AID-JOB920>3.0.CO;2-V

Hollingshead, A. B., \& McGrath, J. E. (1995). Computer-assisted groups: A critical review of the empirical research. In R. A. Guzzo \& E. Salas (Eds.), Team effectiveness and decision making in organizations (pp. 46-78). San Francisco: Jossey-Bass.

Hom, P. W., R. W. Griffeth, and C. L. Sellaro. (1984). The Validity of Mobley's (1977) Model of Employee Turnover. Organizational Behavior and Human Performance, 34, 141-174, doi:10.1016/0030-5073(84)90001-1, http://dx.doi.org/ doi: 10.1016/0030-5073(84)90001-1

Huszczo, G. (1990). Training for team building. Training and Development Journal, Vol. 44 No. 2, pp. 37-43.

Kahn,W. (1990). Psychological conditions of personal engagement and disengagement at work. Academy of Management Journal, Vol. 33, 692-724. doi:10.2307/256287, http://dx.doi.org/10.2307/256287

Kanungo, R.N. (1979). The concepts of alienation and involvement revisited. Psychological Bulletin, Vol. 86, 119-38, doi:10.1037/0033-2909.86.1.119, http://dx.doi.org/10.1037/0033-2909.86.1.119

Kanungo, R.N. (1982). Measurement of job and work involvement. Journal of Applied Psychology, Vol. 67 No. 3 , pp. 341-9. doi:10.1037/0021-9010.67.3.341, http://dx.doi.org/10.1037/0021-9010.67.3.341

Lawler, E.E. (1971). Pay and Organizational Effectiveness: A Psychological View. McGraw-Hill, New York, NY. Lawler, E.E. (1986). High-involvement Management: Participative Strategies for Improving Organizational Performance. Jossey-Bass, San Francisco, CA.

Lawler, E.E. III, Mohrman, S.A., and Ledford, G.E. Jr. (1992). Employee Involvement in Total Quality Management: Practices and Results in Fortune 1000 Companies. Jossey-Bass, San Francisco, CA.

Lee S.M. (1971). An empirical analysis of organizational identification. Academy of Management Journal, 14(2), 213-226. doi:10.2307/255308, http://dx.doi.org/10.2307/255308

Lodahl T. M., and M. Kejner. (1965). The Definition and Measurement of Job Involvement. Journal of Applied Psychology, Vol. 49, 24-33. doi:10.1037/h0021692, http://dx.doi.org/10.1037/h0021692.

Manojlovich, M., Laschinger, S., \& Heather, K. (2002). The relationship of empowerment and selected personality characteristics to nursing job satisfaction. Journal of Nursing Administration, 32(11), 586-595. doi:10.1097/00005110-200211000-00006, http://dx.doi.org/10.1097/00005110-200211000-00006.

Mohrman, A.M., Rensic-West, S.M., and Lawler, E.E. (1989). Designing Performance Appraisal System: Aligning Appraisals and Organizational Realities. Jossey-Bass, San Francisco, CA.

Munene, J.C. (1995). Not-on-seat: an investigation of some correlates of organizational citizenship behaviour in Nigeria. Applied Psychology: An International Review, Vol. 44, No. 2, 111-22. doi:10.1111/j.1464-0597.1995.tb01069.x, http://dx.doi.org/10.1111/j.1464-0597.1995.tb01069.x

Nadler, D., Hackman, J.R., and Lawler III E.E. (1979). Managing Organizational Behavior. Little Brown, Boston. 
Nunnaly, J.C., \& Bernstein, I.H. (1994). Psychometric theory. New York: McGraw-Hill.

Passos, Ana Margarida and Caetano Anto'nio. (2005). Exploring the effects of intragroup conflict and past performance feedback on team effectiveness. Journal of Managerial Psychology, Vol. 20 No. 3/4, 231-244. doi:10.1108/02683940510589028, http://dx.doi.org/10.1108/02683940510589028

Paullay, I.M., Alliger, G.M., Stome, R., and Eugene, F. (1994). Construct validation of two instruments designed to measure job involvement and work centrality. Journal of Applied Psychology, Vol. 79 No. 2, pp. 224-8. doi:10.1037/0021-9010.79.2.224, http://dx.doi.org/10.1037/0021-9010.79.2.224

Pfeffer, J. (1994). Competitive advantage through people. Boston: Harvard Business School Press.

Rabinowitz, S., \& Hall, D. T. (1977). Organizational research on job involvement. Psychological Buletin, 84, 265-288. doi:10.1037/0033-2909.84.2.265, http://dx.doi.org/10.1037/0033-2909.84.2.265

Rotenberry, Paul F., and Moberg, Philip J. (2007). Assessing the impact of job involvement on performance. Management Research News, Vol. 30 No. 3, 203-215. doi:10.1108/01409170710733278, http://dx.doi.org/10.1108/01409170710733278

Schermerhorn, John R. Jr. (2008). Management, 9th Edition. John Wiley \& Sons, Inc., New Jersey.

Simon, L.C. (2001). "Study of the performance of student teams in engineering education", unpublished master's thesis, University of Nebraska, Lincoln, NB.

Solansky, Stephanie T. (2008). Leadership Style and Team Processes in Self-Managed Teams. Journal of Leadership \& Organizational Studies, Vol. 14 No. 4 May, 332-341. doi:10.1177/1548051808315549, $\mathrm{http}: / / \mathrm{dx}$.doi.org/10.1177/1548051808315549

Soong, S. W. (2000). The study on the devotion and job satisfaction of adults' participation in volunteer services. Taiwan: National Kaohsiung Normal University.

Tuckman, B.W. (1965). Developmental Sequence in Small Groups. Psychological Bulletin, 63, 384-99. doi:10.1037/h0022100, http://dx.doi.org/10.1037/h0022100

Warkentin, M. E., Sayeed, L., \& Hightower, R. (1997). Virtual Teams versus face-to-face teams: An exploratory study of a Web-based conference system. Decision Science, 28, 975-996. doi:10.1111/j.1540-5915.1997.tb01338.x, http://dx.doi.org/10.1111/j.1540-5915.1997.tb01338.x

Wimalasiri, Jayantha S., and Kouzmin, Alexander. (2000). A comparative study of employee involvement initiatives in Hong Kong and the USA. International Journal of Manpower, Vol. 21 No. 8, 614-634. doi:10.1108/01437720010379510, http://dx.doi.org/10.1108/01437720010379510

Yang, Hui-Ling, Kao, Yu-Hsiu, and Huang, Yi-Ching (2006). The Job Self-Efficacy and Job Involvement of Clinical Nursing Teachers. Journal of Nursing Research, Vol. 14, No. 3, 237-249. doi:10.1097/01.JNR.0000387582.81845.57, http://dx.doi.org/10.1097/01.JNR.0000387582.81845.57

Table 1. Independent sample t-test and ANOVA for demographic characteristics

\begin{tabular}{|l|c|c|c|l|}
\hline & Test & Value & $\mathrm{df}$ & Sig \\
\hline Gender & Independent sample t-test & $\mathrm{t}=1.006$ & 174 & .316 \\
\hline Marital Status & Independent sample t-test & $\mathrm{t}=1.168$ & 174 & .244 \\
\hline Educational Level & ANOVA & $\mathrm{F}=4.631$ & 3,172 & .004 \\
\hline
\end{tabular}

Table 2. Descriptive statistics and reliability of study variables

\begin{tabular}{|l|c|c|c|}
\hline Variables & Mean & Std. Deviation & Cronbach`s Alpha \\
\hline 1. Employee Empowerment & 4.254 & .492 & .879 \\
\hline 2. Teamwork Effectiveness & 3.962 & .706 & .854 \\
\hline
\end{tabular}

Table 3. One Sample t-test

\begin{tabular}{|l|c|c|c|}
\hline \multirow{2}{*}{} & \multicolumn{3}{|c|}{ Test Value $=3$} \\
\cline { 2 - 4 } & $\mathrm{t}$ & $\mathrm{df}$ & Sig. (2-tailed) \\
\hline Employee Involvement & 33.846 & 175 & .000 \\
\hline Teamwork Effectiveness & 18.082 & 175 & .000 \\
\hline
\end{tabular}

Table 4. Linear Regression Analysis

\begin{tabular}{|c|c|c|c|c|}
\hline $\mathrm{R}^{2}$ & F test value & Sig & Beta & Std. Error \\
\hline .632 & 299.176 & .000 & .795 & .066 \\
\hline
\end{tabular}

